University of Montana

ScholarWorks at University of Montana

2013

\title{
The Search for "Strong Medicine": Pathways to Healthcare Development in Remote Nepal Using GIS
}

\author{
Catherine Lee Sanders \\ The University of Montana, catherine.sanders@umontana.edu \\ Kimber Haddix McKay \\ University of Montana - Missoula, kimber.mckay@mso.umt.edu
}

Follow this and additional works at: https://scholarworks.umt.edu/anthro_pubs

Part of the Anthropology Commons

Let us know how access to this document benefits you.

\section{Recommended Citation}

Sanders, Catherine Lee and McKay, Kimber Haddix, "The Search for "Strong Medicine": Pathways to Healthcare Development in Remote Nepal Using GIS" (2013). Anthropology Faculty Publications. 13.

https://scholarworks.umt.edu/anthro_pubs/13

This Article is brought to you for free and open access by the Anthropology at ScholarWorks at University of Montana. It has been accepted for inclusion in Anthropology Faculty Publications by an authorized administrator of ScholarWorks at University of Montana. For more information, please contact scholarworks@mso.umt.edu. 


\title{
THE SEARCH FOR “STRONG MEDICINE": PATHWAYS TO HEALTHCARE DEVELOPMENT IN REMOTE NEPAL USING GIS
}

\author{
Catherine L. Sanders*† and Kimber H. McKay*† \\ *Department of Anthropology, University of Montana, Missoula, MT, USA \\ $\dagger$ The ISIS Foundation, Edmonds, WA, USA
}

\begin{abstract}
Nepalese agropastoralists' confrontations with forces of change in the last generation have altered villagers' abilities to gain access to health services, clean water, and nutrition in Humla District, Nepal. Development efforts and Nepal's recent armed conflict, in particular, introduced novel technologies and ideologies that a subsection of villagers have responded to in a fashion that we did not expect. In this article, based on theories about the diffusion of innovation and risk, we argue that, together, villagers and other change agents have cocreated new contexts of vulnerability in the postconflict setting of rural Nepal, as observed in remote Humla District. Using ArcGIS to represent landscapes of health and health-seeking behavior, we explore the integration of neoliberal health development in this postconflict setting in which medical pluralism, caste, Hinduism, and cultural conservatism all shape decision making. Based on in-depth and long-term research conducted in the region over the past 15 years, we describe the strengths and weaknesses of GIS as a tool for enhancing our understanding of this "health landscape." In Humla, topography is a major determinant of access to healthcare. Our analyses reveal interesting relationships among health, culture, and vulnerability and provide insight into directions for future health interventions in similar contexts elsewhere.
\end{abstract}

Key words: Health; Health seeking; Development; Geographical information system (GIS); Vulnerability

\section{INTRODUCTION}

In countries throughout the Global South, healthcare development has been neglected by failing governments and bequeathed to a patchwork of nongovernmental organizations (NGOs) funded by international donors $(24,52)$. NGOs provide essential services that would otherwise leave masses of people without basic tools of survival (e.g., sewage disposal, nutritional supplementation, and medicine). However, the uncoordinated efforts of many NGOs, their emphasis on neoliberal values, and lack of oversight provoke many criticisms. In remote parts of Nepal, villagers struggle to receive adequate healthcare despite the ever increasing numbers of NGOs providing services in the region. Reasons for this gap include external issues, such as the mountainous terrain that precludes the building and maintenance of extensive healthcare infrastructure and internal issues of inappropriate program design and low levels of trust between organizations and the communities they serve (25). With the help of GIS imagery and analyses, this article reveals the ways in which the natural and human-made landscape shape access to healthcare in Humla. It uses a microanalytical framework to reveal information not often available in the literature. We posit that the interactions between local people, outsiders, and the landscape help to determine who gets access to what health resources, with some

Accepted December 11, 2012

Address correspondence to Catherine L. Sanders, Research Associate, The ISIS Foundation, 823 Wolf Ave \#3, Missoula, MT 59802, USA. Tel: (406)-552-9483; Fax: (406)-728-3328; E-mail: catherine.sanders@isisgroup.org 
surprising implications for the relationship between health and socioeconomic status in rapidly developing regions like Humla District. Using GIS-generated imagery, we show that wealthier people $d o$ have better access to healthcare resources; however, due to complications of the transition to a new healthseeking regime, better access to health services does not necessarily lead to better health outcomes. The results point to ways in which healthcare development agents can improve service delivery in remote, rapidly developing regions.

The villages in the field site are located $12 \mathrm{~km}$ from the district capital in a roadless Himalayan valley in northwestern Nepal (Fig. 1). The field site includes two villages, Paschimgaon and Uttargaon (pseudonyms), of similar size whose inhabitants belong, for the most part, to the second-to-highest ranking Hindu caste in the Nepali caste system (the Thakuri jaat). A census we conducted in 2009 and 2010 revealed that Paschimgaon had a population of 420 individuals in 67 households, while Uttargaon housed 386 people in 61 households (Fig. 2). Despite a community health model instituted in the late 1970s by the Nepali government and the intense activities of governmental and nongovernmental aid organizations in the region since the early 1990s, villagers' sicknesses are still what the medical community characterizes as "preventable" $(4,28)$. Like many people living in rural regions of the developing world, Humli villagers typically suffer from infectious diseases that have been largely eradicated in the developed world. Tuberculosis, polio, and leprosy affect villagers, along with a variety of respiratory and food- and water-borne diseases that result from a combination of indoor air pollution from cooking fires and lacking hygiene and sanitation technologies. Water and food sources are contaminated with protozoa, viruses, and/ or bacteria, and villagers struggle in every season with diarrheal and respiratory diseases that contribute to infant mortality, days lost from work, and other morbidity and mortality (Table 1). Injuries resulting from landslides and falls on steep mountain paths are other frequent occurrences in Humla District and are usually attended to within the village. Respiratory infections account for a large proportion of morbidity and mortality and are caused or worsened by poor ventilation and indoor cooking fires, combined with poorer air quality at high altitudes and local smoking habits. High and physiologically taxing labor demands resulting from a livelihood that relies on production from agriculture, trade, and livestockraising seem to exacerbate the burden of disease in this population, particularly in the planting and harvesting seasons $(35,38)$.

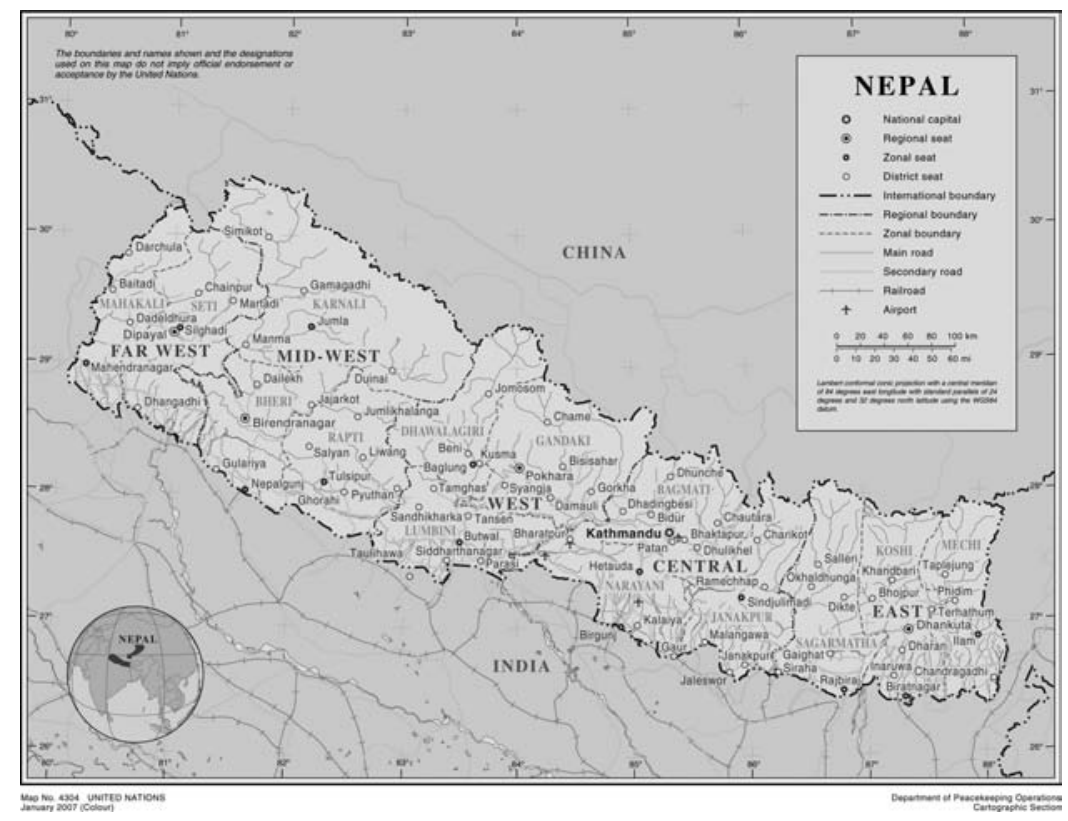

Figure 1. Remote Humla District, Nepal. 


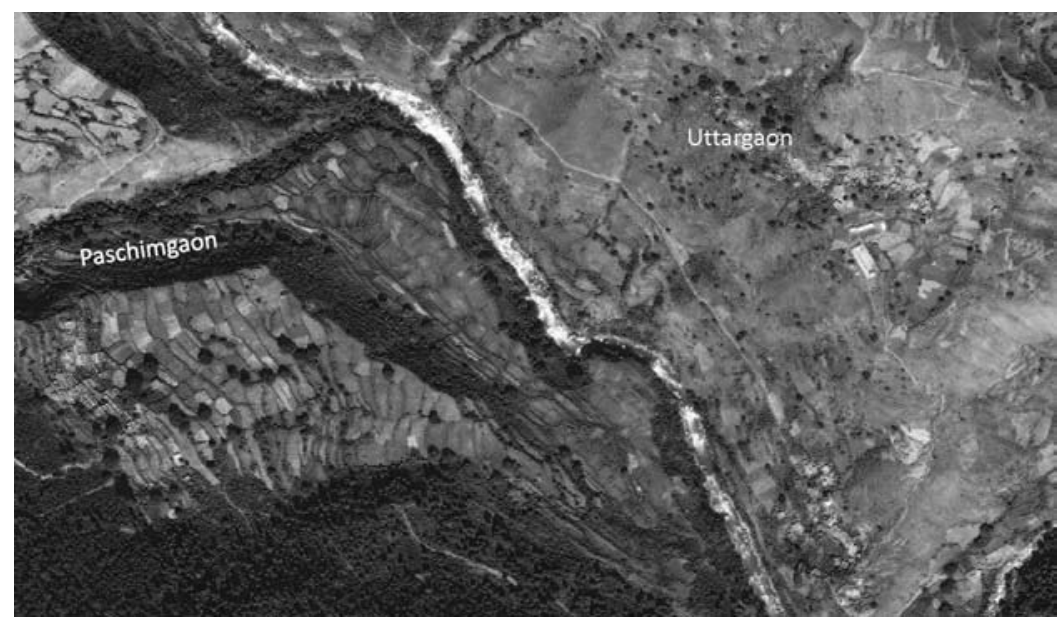

Figure 2. The villages in the fieldsite have distinct geographical feature.

Nearly half of the complaints for which we were able to collect health-seeking data were for acute gastrointestinal (GI) difficulties, most likely the result of bacterial and viral infections contracted through food and water contaminated by livestock. Healthcare decisions for GI problems were similar to overall health seeking, in that the first response was typically to send someone in the household to get drugs from a nearby health clinic or a pharmacy in the district capital, Simikot, $12 \mathrm{~km}$ away. Herbal treatments of GI problems took a slightly higher third place among first treatments than that for sicknesses overall (Table 2). The period of time people waited to seek a first line of treatment was also fairly consistent across sickness categories, with the majority of first treatments occurring within the first 3 days of sickness.

As of 2010, one public hospital in Simikot served all inhabitants of northern Humla. It was irregularly staffed because the doctors posted by the government to work in Simikot tend to spend a considerable amount of time outside of Humla District (12,30). This means that undertrained staff are generally responsible for diagnosis and treatment, so the quality of care Humlis can receive there is quite low. A private institution with more funding, equipment, and supplies is nearby, with new facilities and the only $\mathrm{X}$-ray machine in Humla, but anecdotal evidence suggests that most Humlis view the cost of treatment there as prohibitive and the hospital is often empty. The government health clinic infrastructure remains, consisting of health posts in more-or-less every other village, either completely locked up and devoid of equipment and medicine or staffed by untrained health volunteers who dispense whatever medicines are available. A few nongovernmental organizations have instituted clinic systems in attempts to fill in the holes in government coverage.

The Thakuris of northern Humla identify as high-ranking members of the Nepali Hindu caste system, but their religious practices more closely

Table 1. Sickness and Treated Sickness in the Field Site

\begin{tabular}{lccccc}
\hline & \multicolumn{2}{c}{ All Sickness } & & \multicolumn{2}{c}{ Treated Sickness } \\
\cline { 2 - 3 } \cline { 5 - 6 } & $\begin{array}{c}\text { Frequency } \\
\text { (Occurrences) }\end{array}$ & $\begin{array}{c}\text { \% of All } \\
\text { Sickness }\end{array}$ & & $\begin{array}{c}\text { Frequency } \\
\text { (Occurrences) }\end{array}$ & $\begin{array}{c}\text { \% of All } \\
\text { Treatments }\end{array}$ \\
\hline Gastrointestinal & 149 & 23.7 & & 105 & 40.9 \\
Fever & 104 & 16.5 & & 55 & 21.4 \\
Cough & 88 & 14.0 & & 16 & 6.2 \\
Injury & 76 & 12.1 & & 18 & 7.0 \\
Minor infection & 65 & 10.3 & & 21 & 8.2 \\
Flu & 36 & 5.7 & & 12 & 4.7 \\
Other & 79 & 12.7 & & 17 & 6.7 \\
Total & 629 & 100 & & 257 & 100 \\
\hline
\end{tabular}


Table 2. First Treatments for Overall and Gastrointestinal Sickness in the Fieldsite

\begin{tabular}{lccccc}
\hline & \multicolumn{2}{c}{ 1st Treatment: All Sicknesses } & & \multicolumn{2}{c}{ 1st Treatment: GI } \\
\cline { 2 - 3 } & Frequency & Percent & & Frequency & Percent \\
\hline Pharmacy-nearby & 81 & 31.5 & & 34 & 32.4 \\
Pharmacy-Simikot & 61 & 23.7 & & 30 & 28.6 \\
Herbs & 48 & 18.7 & & 26 & 24.8 \\
Simikot medical treatment & 24 & 9.3 & & 6 & 5.7 \\
None & 23 & 8.9 & & 3 & 2.9 \\
Dhami & 17 & 6.6 & & 5 & 4.8 \\
Treatment in distant urban center & 2 & 0.8 & & 1 & 0 \\
Other & 1 & 0.4 & & 0 & 1.0 \\
Total & 257 & 100.0 & & 105 & 100.0 \\
\hline
\end{tabular}

resemble animistic, ancestor-centric religions practiced by their predecessors who migrated to the Himalayas from India's Gangetic plain over 500 years ago $(5,6,26,36,40)$. In addition to the difficulties of access to healthcare services in an environment characterized by scarcity and unpredictability, healthseeking patterns in the region are complex, due to pluralistic health-seeking practices resulting from the syncretism between Buddhism and Hinduism (29) and, more recently, from the introduction of biomedical systems from the Western world (34) and the Maoist conflict (1996-2006) that made travel for treatment unsafe and more costly (12,50).

Villagers respond to development workers and their programs in complicated ways. On the one hand, rural villagers often have reputations for being among the most "backward" of all Nepali citizens (51) and wish to become "developed." On the other hand, the organizations that have requested their labor in programs have fulfilled few of their development promises (25). When the workers leave and the projects end, NGOs often neglect the unfinished or broken irrigation systems, greenhouse projects, or orchards that are difficult to maintain locally and relegate villagers to a more precarious position than when the projects began. Paired with their long-standing disenfranchisement from the government, this situation has made villagers suspicious of outsiders in general $(18,54)$. This was one reason Humlis gave for viewing both Maoist combatants and NGO workers with similar reluctance during the war-both of their claims and concerns were equally foreign, difficult to evaluate, and sounded a lot like the failed promises villagers had heard before.

Despite this ambivalence, most villagers in the field site wanted Western medicines to treat their sicknesses but often could not afford the money, time, and/or risk of failure the use of healthcare services entailed. Local alternatives included herbs and dhamis, or shamans, who heal through their contact with ancestral spirits. Humlis often use traditional treatments in combination with biomedical services. As a result of the aggressive development programs implemented in this part of Humla by Western-based organizations, though, the two most popular health-seeking strategies among villagers in the field site involved the procurement of biomedical services. Biomedical drugs are considered the strongest (sabanda kadaa), or most powerful, of available medicines (56) and the most difficult to access. Even the nearest government village health clinic was nearly $2 \mathrm{~h}$ away, unpredictably staffed by a poorly trained health worker and stocked with a bare minimum of supplies. Going there meant that one or two members of the household took a valuable half-day away from the fields to arrive at a locked door. Alternatively, sick people walked $12 \mathrm{~km}$ and climbed $1,500 \mathrm{~m}$ in elevation to the hospital or a pharmacy in Simikot (Fig. 3). Doctors from urban regions of Nepal spend 2-year stints in rural hospital postings, but they are usually posted far away from their homes and have little incentive to invest a great deal of energy in the temporary posting (31). Depending on how sick and/or persistent a person is, villagers might spend several days awaiting treatment or medicine in Simikot.

In mountain ecosystems, elevation, rough terrain, livelihood systems, and climate change may make decisions about health, among other concerns, contingent on the season, especially where agriculture forms the basis of food security $(1,49)$. If it is harvest or plowing season, time constraints on health seeking are an even greater issue, often delaying 


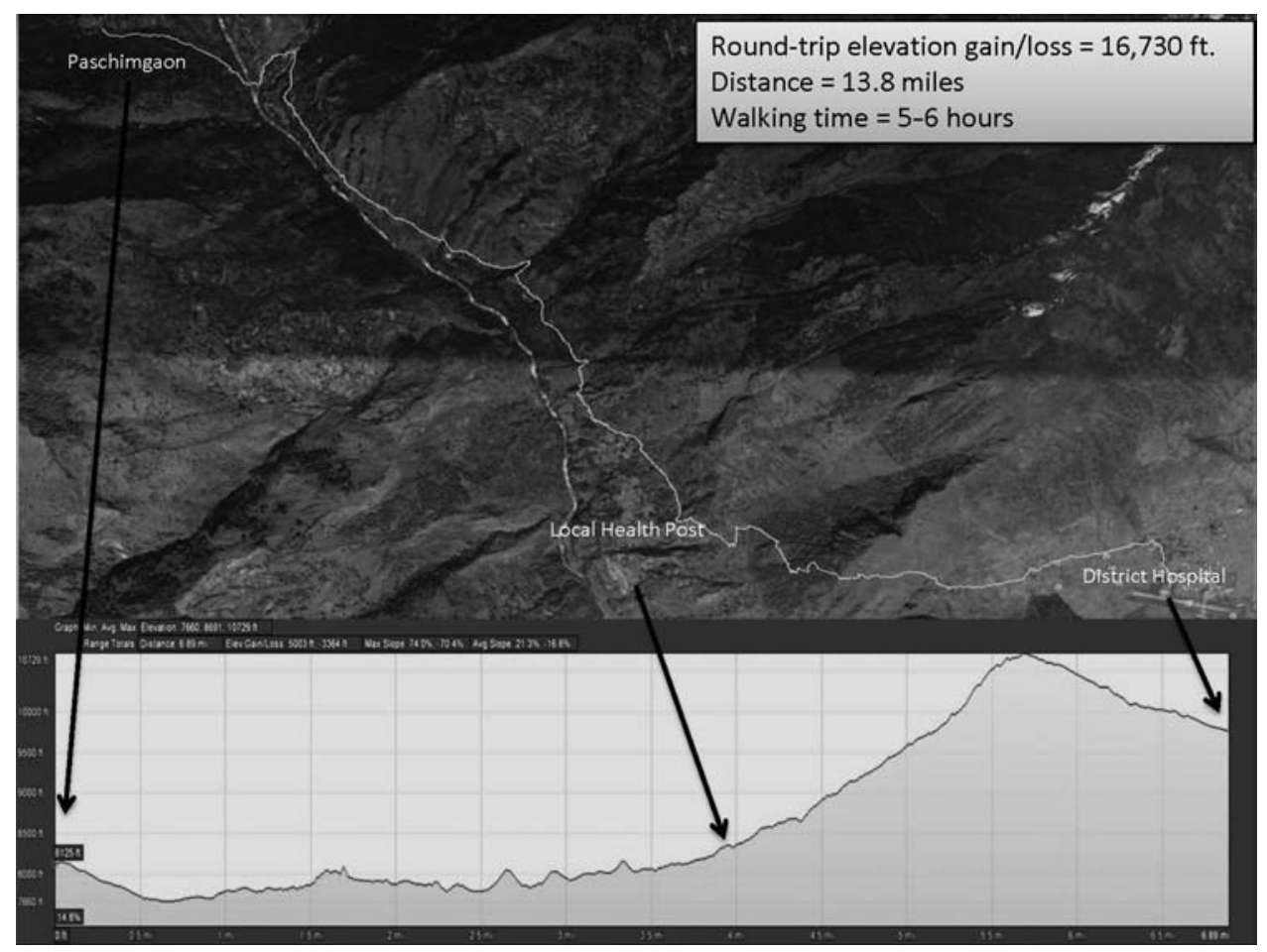

Figure 3. Digital Globe imagery illustrates the difficult walking path to treatment services in the district capital.

treatment processes beyond the critical period (33). Because villagers are so dependent on labor-intensive economic pursuits, health-seeking in remote areas often involves tough sacrifices on the part of the sick person and their family members $(20,48)$. In this field site, we found that labor demands associated with agricultural seasons often dictated the kinds of sicknesses people experienced, as well as their decisions about treating sickness.

In Humla, kin networks have traditionally been the main source of social support. Social networks (i.e., friends and family) reduce vulnerability by providing material and emotional supports, additional caretaking, and relief from labor burdens that prevent undue stress on the body (57). They may also enhance vulnerability and sickness by creating social exclusions that bar access to important health resources $(22,37,43,55)$.

When NGOs enter the vulnerability equation, additional dynamics may affect the social and material resources available. NGOs tend to espouse neoliberal ideologies that emphasize individual-level decision making about economics and healthcare. The social networks interacting with NGO programs and workers begin to shift as a result of these influences and the changes in mobility and economic structure that often accompany NGO-led development (15). Economies tend to become more cash-based, and certain people are better-positioned to enter into novel economic relationships and pursuits (11). Here, we explore possible associations between social networks, development, and health vulnerability in Humla.

Geographical information systems (GIS) revealed patterns in terms of kinship as well as seasonality, otherwise obscured, that appeared to be related to health vulnerability and health seeking. When we combined social features with GIS in new ways, patterns emerged that revealed a gap between health services and health outcomes in Humla District. Sickness and the ways in which villagers confront it are conscribed by the seasonal, topographical, and policy dynamics characteristic of remote developing world contexts. The ways in which these dynamics influenced individual decision makers in shaping health landscapes in Humla form patterns discernible via GIS at the level of microanalysis and revealed a health-seeking transition that left unexpected segments of the population vulnerable to poor health outcomes. 


\section{METHODS}

The results presented here are primarily based on fieldwork conducted in 2009-2010 by the first author, supplemented with ethnographic information from the authors' combined 17 years of experience in the region that provide explanation and context for the statistical findings. In IRB-approved 2009-2010 fieldwork, the first author conducted 308 surveys among male and female members of the 128 households comprising the two villages, Paschimgaon and Uttargaon. Surveys measured attitudes toward development projects and processes in the field site, adoption of said programs, and villager vulnerabilities in terms of access to a broad range of resources, including cash, agricultural productivity, labor, health, social supports, and natural resources. Paschimgaon had a reputation for being particularly reluctant to engage with development programs. Uttargaon is located nearby and is one of the few villages in the region of similar size, ethnic make-up, and religious observance to Paschimgaon, allowing for comparisons that might reveal underlying causes for Paschimgaon's conservatism. Surveys were conducted in three separate seasons (harvest, winter, and spring) so as to take into account nutritional and workload variation, and they measured villagers' material and social resources, health and health-seeking behavior, and attitudes about development. In addition, key informant interviews, participant observation and many informal conversations with villagers during a year of fieldwork in the villages yielded much about the attitudes and day-to-day challenges and opportunities villagers confronted when dealing with health issues.

A Garmin eTrex Vista HCx GPS was used to generate data for remote sensing, since this region and the features that comprise health seeking in Humla lie outside the limits of adequate GIS satellite coverage. User-equivalent range errors averaged $12 \mathrm{~m}$ during use in the field. Treatment pathways and kin relationships were processed using geodetic lines to represent relationships between two points with geospatial attributes (2). In order to produce a map that shows a network of connections among sets of these pathways/relationships, household locations were digitized in ESRI's ArcMap 10, using a Worldview 1 image base layer, and their associated distance and latitude and longitude locations attached to the kin network and health-seeking data sets. Using these locations to define the start and end of a treatment pathway or kin relationship, ArcMap's XY-to-line tool created connections between households that match the pathway or relationship of that household as defined in the input table. These connections were further summarized using custom categorical symbols within ArcMap to help make inferences about pathways and relationships. After consideration of some of the other ways of connecting points in Arc, we chose the XY-to-line tool because it creates a variable for the distances between two points, as well as rendering visible the social patterns observed in the field. Judging from a review of the literature and the reactions of the GIS specialists with whom we consulted, we are pioneering this particular technique of portraying social relationships in ArcGIS.

Analyses and imaging in ArcGIS were supplemented by statistical analyses of the relationships between health and socioeconomic status (SES) indicators conducted primarily in IBM's SPSS version 20. Because we were using ArcGIS in innovative ways in order to reveal social network features and their impacts on decision making, we consulted with several GIS specialists and experimented with a few ways of modeling the data in ArcGIS. Where ArcGIS images were less informative, we used Google Earth to represent information about pathways to treatment. The combination of ArcGIS, SPSS, and Google Earth provide unique insights into health seeking in this region, where the mountains and the topographical constraints they pose so heavily influence people's day-to-day activities and access to the services provided by NGOs and the government.

\section{VILLAGE-LEVEL VARIATION}

Despite their physical proximity to one another and many other demographic and cultural similarities, the two villages in the field site varied in several important ways. In this article we examine these and other differences in terms of what they reveal about development processes and health determinants and outcomes in this Himalayan enclave. Due to the poverty, remoteness, and traditional nature of the cultures beset by rapid development processes, these findings will also shed light on healthcare 


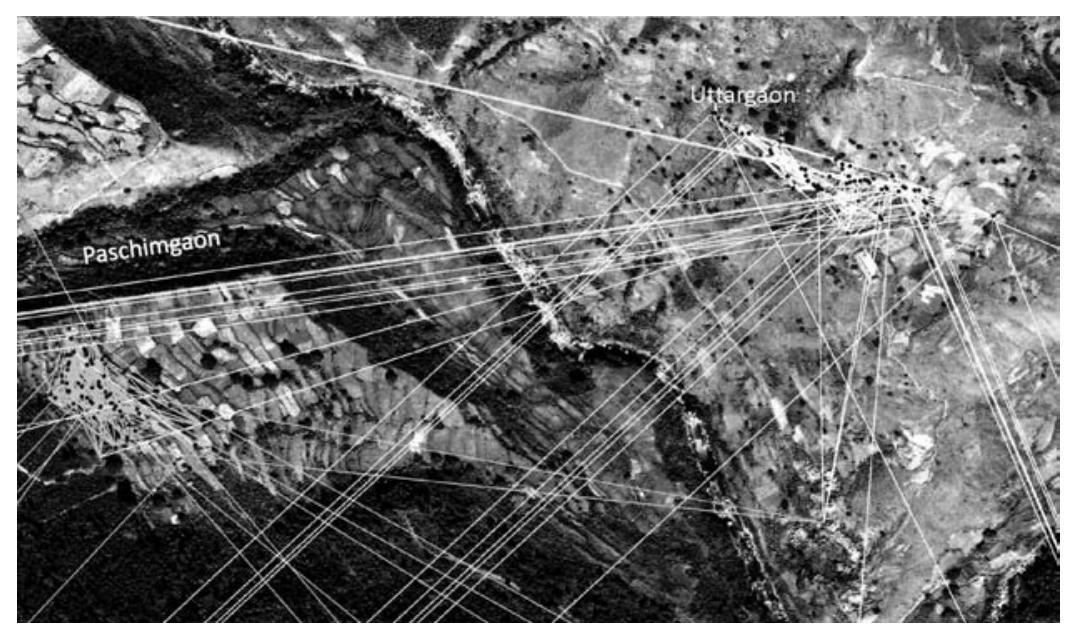

Figure 4. This map linking households sharing "blood" and marital kin connections reveals the denser introverted nature of Paschimgaon's networks, compared to Uttargaon's longer distance, sparser networks (same as Fig. 2).

development in the Global South more broadly. Microclimate variability is quite common in mountainous regions like this one, due to the extremes of topographical variation and impediments and access to resources existing within a few kilometers of one another (7). Different microclimates characterized by local geological and topographical features may pose varying challenges to health access for individuals inhabiting them.

Paschimgaon, unlike the other villages in upper Humla, has flatter, expertly terraced and irrigated lower fields used to plant and harvest a variety of red rice unique to the region. This highly nutritious red rice is essential to many ceremonies among the Thakuri caste in Humla District. Because Paschimgaon villagers own the only land capable of growing this crop, many of these villagers harbor a considerable amount of pride about their ability to grow and furnish their ceremonies with it. In contrast, Uttargaon villagers have access to the least fertile, steepest, and most dispersed agricultural fields, making food security a constant stress for inhabitants.

Beyond their way of earning a living, Paschimgaon villagers are considered more traditional than their neighbors. Their traditionalism may result from their relative geographic isolation (Paschimgaon is bounded on three sides by waterways and chasms that protect their land and forest resources from encroachment by other villages) or could be due to their relative agricultural success. Paschimgaon villagers venture outside of their own village less often than residents of Uttargaon and form a more tightly knit community (Fig. 4). Because of this, they are perceived by other villagers and by NGO workers as conservative and averse to progress. Indeed, Thakuri people from the surrounding villages and sometimes from Bajang and Bajura Districts came to Paschimgaon to learn words to the old folk songs performed during important ceremonies. But Paschimgaon's traditionalism was not always positively heralded. NGO workers often used the word "lazy" as a proxy for their resistance to NGO programs. Paschimgaon did have significantly more residents with disabilities compared to neighboring villages, and outsiders sometimes used this visible disadvantage as an indictment against both the lack of modernity in the village and residents' ability to care for each other. By and large, the negative reputation of Paschimgaon was exaggerated by outsiders, if not completely contrary to what we observed in fieldwork.

Instead, our data revealed that Paschimgaon villagers suffered significantly fewer gastrointestinal and respiratory sicknesses than Uttargaon villagers across seasons (Table 3). Uttargaon villagers had significantly greater sicknesses in every season than their neighbors across the Karnali River, possibly the result of their more intense farming labor requirements, nutritional deficits associated with their poor land quality, and their practice of conducting extensive, 
Table 3. Statistically Significant Village Differences in Well-Being

\begin{tabular}{llcccc}
\hline & Village & $n$ (Households) & Mean & SD & SEM \\
\hline Months of food security this year** & Paschimgaon & 67 & 2.99 & 1.87 & 0.23 \\
& Uttargaon & 61 & 1.48 & 1.55 & 0.20 \\
People suffering gastrointestinal problems* & Paschimgaon & 63 & 0.38 & 0.63 & 0.08 \\
& Uttargaon & 58 & 0.66 & 0.76 & 0.10 \\
People suffering respiratory problems** & Paschimgaon & 53 & 0.11 & 0.32 & 0.04 \\
& Uttargaon & 48 & 0.58 & 0.79 & 0.11 \\
\hline
\end{tabular}

*Significant at $p<0.05$. **Significant at $p<0.01$.

far-flung trade activities [see (32) for a similar situation described among the Garhwali]. Uttargaon villagers invest many hours of work to access and plow their poorer quality and unirrigated fields, only to have mediocre crop yields at best. Remote sensing revealed that the two villages had comparable landholdings, but Uttargaon's fields were on slopes steeper by almost a factor of 2 and spread out over about twice the area of Paschimgaon's landholdings. Difficult mountain landscapes force people to be more flexible about preventing sickness and procuring necessities (47), so Uttargaon villagers are more integrated in businesses resulting from trade with China and more open to development projects that may reduce health stresses. Uttargaon is home to the only secondary school in upper Humla and tends to receive more attention from development agents.

Outsiders often assume Uttargaon villagers are healthier due to the lower rate of disability there and to the fact that, in focus groups, Uttargaon villagers perceived themselves as having higher overall socioeconomic statuses (SES) than that of Paschimgaon villagers, when in fact their food security and health outcomes, measured via surveys during 2009 and
2010, were worse. Aside from disadvantages in terms of health and soil quality, Uttargaon villagers had better income, education, technological development, and perceptions of their own economic status and fared better in terms of SES (SES was a weighted measure of each household's landholdings, food security, labor and education assets, livestock resources, cash and kind income, and social resources) $(14,16,44)$, based on our analyses of survey data. In summary, Uttargaon is worse off in terms of health and land (Table 3), but better off in terms of development and income (Table 4).

Sickness indicators measured by surveys tended to increase as SES decreased, but when the economic concerns of a household competed with individual health concerns (e.g., a sick household member's choice between seeking treatment in another village and sowing the fields), individuals usually prioritized economic concerns. Ethnographic evidence during long-term fieldwork suggests that health concerns were viewed more fatalistically by villagers than economic endeavors were. This perspective is often viewed as biologically irrational but makes sense economically and is corroborated by other research in South Asia (49).

Table 4. Statistically Significant Village Differences in Level of "Development"

\begin{tabular}{llrrrr}
\hline & Village & $n$ (Households) & Mean & SD & SEM \\
\hline Total number of technologies & Paschimgaon & 67 & 1.72 & 1.53 & 0.19 \\
adopted** & Uttargaon & 61 & 2.72 & 1.19 & 0.15 \\
Number of health technologies & Paschimgaon & 67 & 1.22 & 1.10 & 0.13 \\
adopted** & Uttargaon & 61 & 1.72 & 0.58 & 0.07 \\
Socioeconomic status* & Paschimgaon & 67 & 1.57 & 0.49 & 0.06 \\
Total income (in Nepali rupees)* & Uttargaon & 62 & 1.76 & 0.37 & 0.05 \\
& Paschimgaon & 67 & 16490.07 & 16179.15 & 1976.60 \\
Education per number of people & Uttargaon & 61 & 21987.79 & 13905.58 & 1780.43 \\
in household** & Paschimgaon & 67 & 1.47 & 1.18 & 0.14 \\
& Uttargaon & 61 & 2.45 & 1.62 & 0.21 \\
\hline
\end{tabular}

*Significant at $p<0.05$. **Significant at $p<0.01$. 


\section{Village-Level Health Seeking}

Using GIS, we mapped villagers' pathways to treatment. This approach revealed the consequences of decisions about healthcare in two villages with different access to resources and different levels of engagement with development organizations. From 630 sickness episodes recorded in 2009 and 2010 fieldwork, we analyzed 257 health-seeking decisions in ArcGIS and statistical software programs. Decisions about when and how to treat sicknesses were usually negotiated at the household level. Because of the rough terrain, lack of infrastructure, and general scarcity of healthcare and other resources in Humla, these negotiations depended on a variety of factors, including how many people were available either within the household or outside of it to engage in health seeking, what other demands competed for villagers' time and cash resources, the type and severity of sickness, which members of the household were affected, and people's beliefs about the best option for healthcare. These factors played out differently in the two villages.

The most significant differences in health-seeking decisions between the two villages concerned the intensity of treatment. In Uttargaon, household decisions about the first method of treatment for a given sickness were, by and large, much riskier, in that they involved travel over greater distances to biomedical medicine healthcare facilities that had more equipment and charged more for treatment (Table 5). Figure 5 reveals the differences in healthcare choices between the two villages. With the exception of air travel to treatment in the Nepal-Indian border town of Nepalganj, all travel was by foot and frequently involved sick people themselves walking unaided, often at even greater cost to their health. Paschimgaon villagers preferred using only one treatment at a time and preferred to seek treatment locally, either in health

Table 5. First Treatment by Village

\begin{tabular}{lcrr}
\hline & Paschimgaon & Uttargaon & Total \\
\hline No treatment & 16 & 7 & 23 \\
Herbs & 29 & 19 & 48 \\
Dhami (shaman) & 11 & 6 & 17 \\
Health post-nearby & 58 & 23 & 81 \\
Pharmacy-district capital & 16 & 45 & 61 \\
Simikot medical treatment & 5 & 19 & 24 \\
Other & 2 & 1 & 3 \\
Total & 137 & 120 & 257 \\
\hline
\end{tabular}

Pearson chi-square $p=0.000$. clinics or with local herbs or dhamis, to the more costly treatments available farther afield. This is a classic pattern of risk aversion expected among "peasants" in remote places with scarce resources $(23,41,53)$.

In comparison, Uttargaon villagers' treatment decisions more closely resemble a group of people who are in what we would call a health-seeking transition. This transition appears to be the result of the degree to which they have been affected by neoliberal economic development. As Uttargaon villagers have ventured out of their village in search of economic opportunities along the path to China and in urban centers in Nepal, they are often paid in cash that they can exchange for processed foods, medicines, and other goods and services. Humli villagers are paid for road work in both cash and kind (i.e., with white rice donated by the international community to the World Food Program that manages a road-building project in upper Humla). Humli villagers are aware that the white rice they receive from international donors is of a lower nutritional quality than their own millet, red rice, amaranth, wheat, and barley crops. They feel they have little choice in the matter, because their agricultural yields are on the decline due to soil erosion and nutrient leaching, increasingly unpredictable weather patterns, and emerging crop diseases. In addition, Uttargaon villagers' engagements with neoliberal economic development have precipitated a shift in the social organization of that village, which is reflected in their diffuse and geographically extensive social networks, as seen in Figure 4 (13). Men are the ones who earn cash outside of the village, for the most part, and cash resources typically are not subject to the group management that, for instance, land and cattle resources must be (27), so decision making and travel outside the village have become more individualized in Uttargaon. We saw that Uttargaon villagers were more likely to pursue work outside of the village and that they vigorously pursued social, economic, and political connections in urban areas of Nepal and China. This does not mean that Uttargaon villagers have thrown off the values they associate with traditional kin groups, social exchange, and support, but that they are mobilizing them in new ways in order to adapt to the increasing scarcity of resources at home.

Though worse off in terms of locally available food and water resources, Uttargaon villagers' higher degree of engagement with development processes prepared them to respond individually and with alacrity 


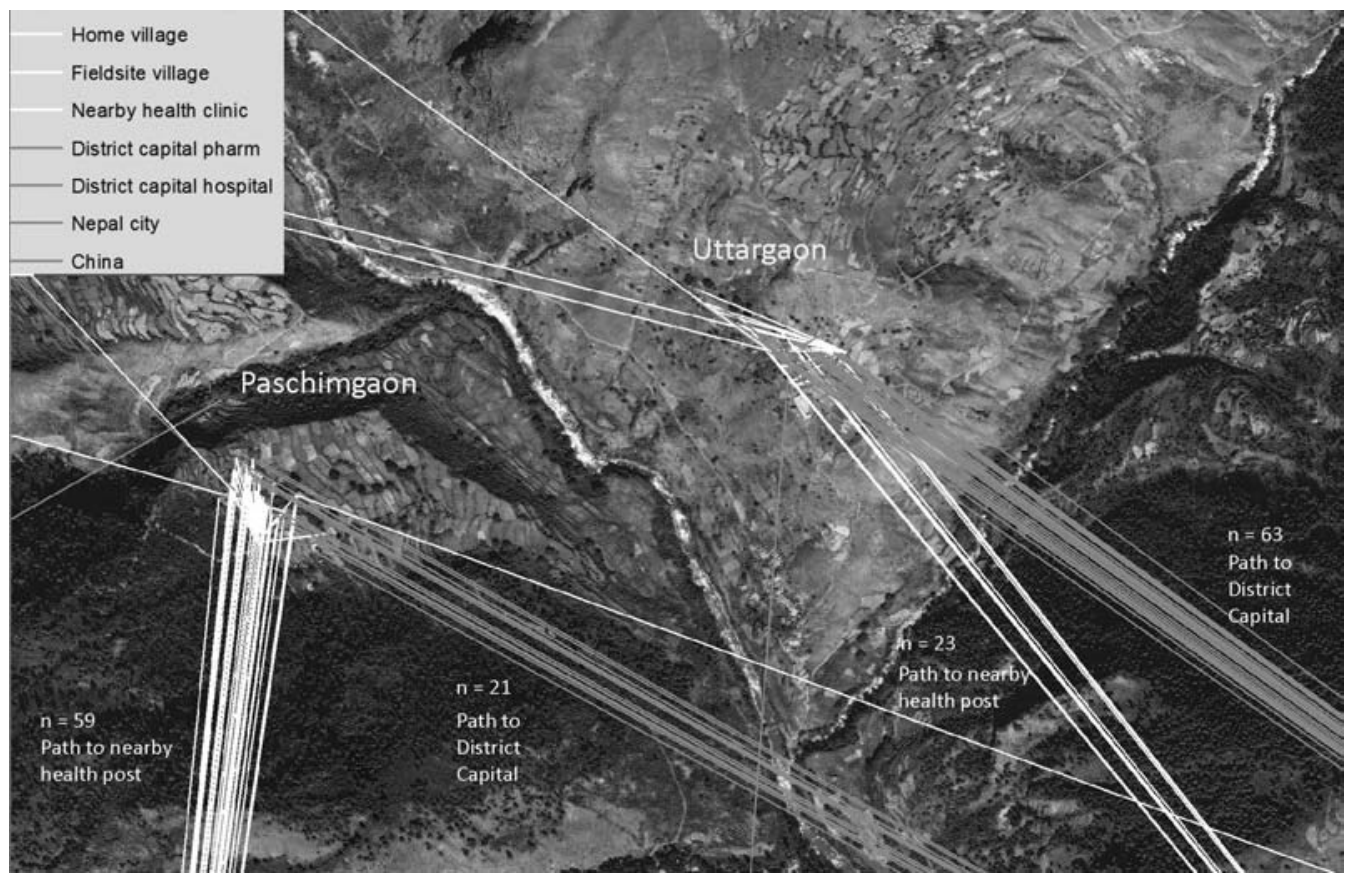

Figure 5. First method of sickness treatment in the fieldsite.

to modern healthcare systems. In Humla, these systems are built on cash payments, and patients travel farther than other Nepalis to access healthcare services and, once there, have to contend with treatment courses based on Western values of equality, individuality, and self-sufficiency. Simultaneously, changes in social and economic factors seem to have set Uttargaon villagers up for worse health outcomes in the first place.

The theory of epidemiologic transition (46) posits that, as populations become more developed and gain local industries and extensive healthcare infrastructures, infectious diseases decline while chronic conditions arise. Even within this health microclimate, we found that during 2009-2010, Uttargaon villagers suffered more chronic sicknesses than Paschimgaon villagers (Table 6). Evidence suggests that increasing rates of sickness in this transitioning community are due to lack of proper nutrition, diet diversity, and labor increases during the interim period before the healthcare infrastructure can catch up to economic reform. In this way, Paschimgaon's "risk aversion" may shield those villagers from the negative health effects of this transition, while also putting them at a disadvantage in terms of economic futures in a rapidly developing region.

\section{Socioeconomic Status and Health}

With the help of GIS, we observed the ways in which seasonality and geographical features influenced health vulnerability and health seeking. In general, the wealthier the households of upper Humla, the less sickness they experienced (Fig. 6). However, male sicknesses tended to be distributed more evenly across socioeconomic classes than that

Table 6. Chronic Sickness by Village

\begin{tabular}{llccc}
\hline & & Paschimgaon & Uttargaon & Total \\
\hline Type of sickness/symptoms & Chronic pain & 12 & 3 & 15 \\
& Chronic weakness & 7 & 8 & 15 \\
& Asthma & 4 & 8 & 12 \\
& Other chronic condition & 7 & 26 & 32 \\
& Total & 30 & 45 & 75 \\
\hline
\end{tabular}

Pearson chi-square $p=0.003$. 


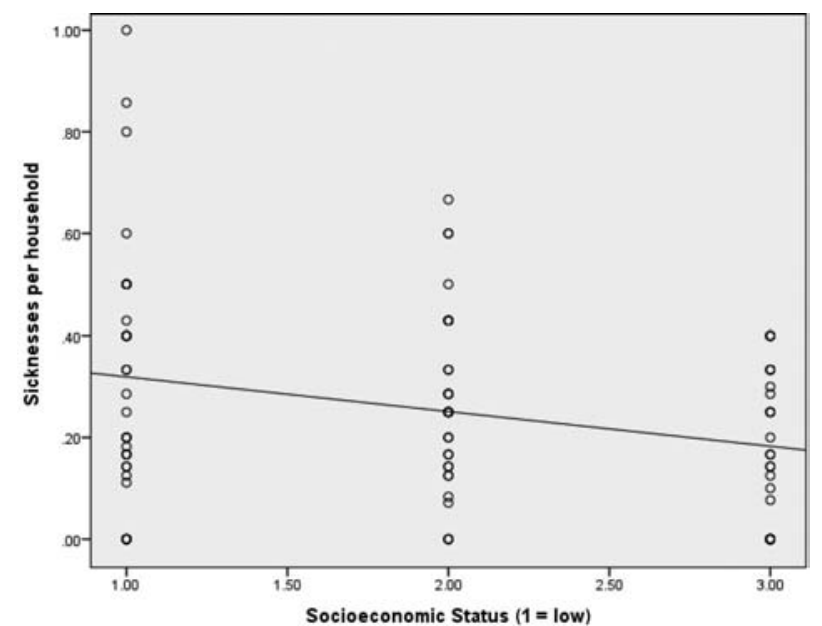

Figure 6. In general, as socioeconomic status increased, sickness decreased.

of females (Fig. 7). Female health in Humla is more dependent on wealth than male health, since females tend to be more confined by Hinduism-influenced social roles connected with class status. They also have less freedom to pursue economic opportunities and less access to the individualized distribution of resources that cash entails. In the political meetings in the villages at which women were present, male expenditures on gambling revenue, alcohol, and cigarettes were the most common female complaints, and in interviews, women were often unaware of how much their husbands were making and/or spending on such leisure activities (10\% of their total expenditures, on average).
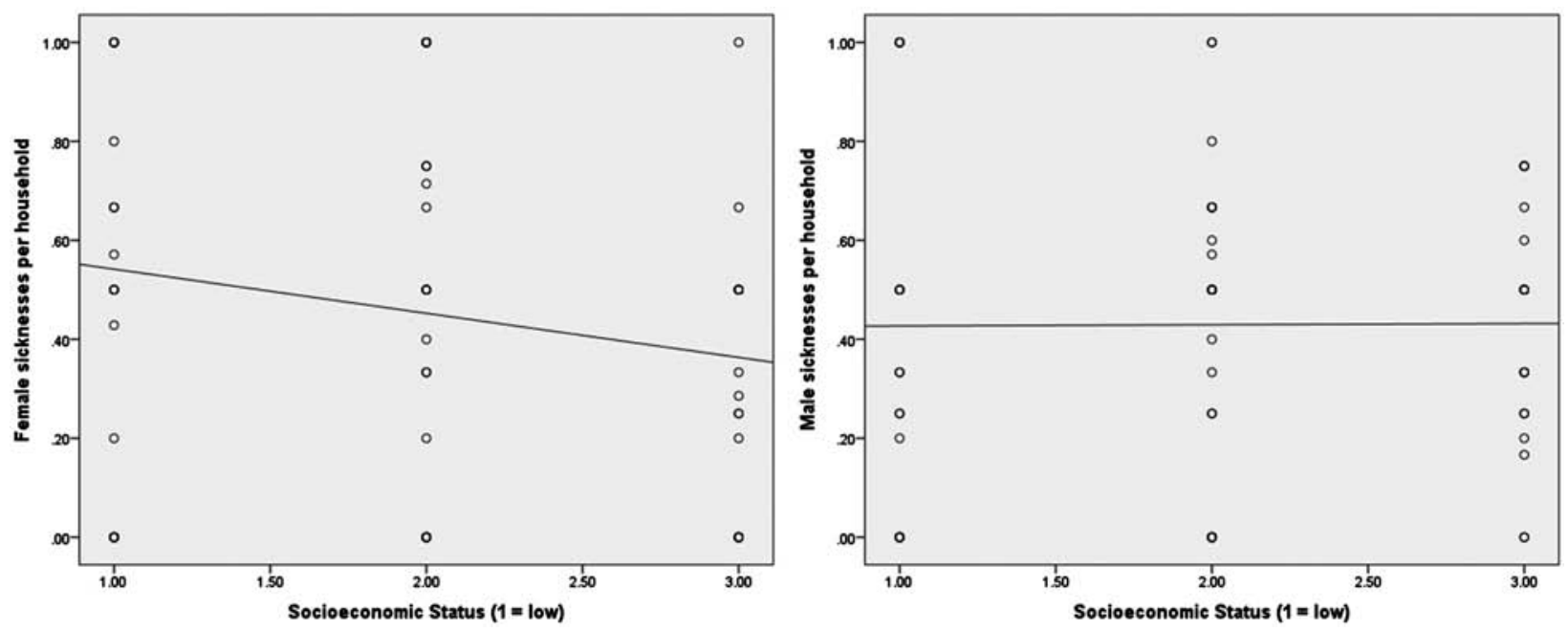

Households with more adult producers had better health outcomes. Since multiple males in traditionally agropastoral households allow for simultaneous participation in agricultural duties at home, trade endeavors afield, and other business engagements, male and female members of multimale households experience fewer labor burdens and greater prosperity than single-male households (28). Households with higher male-female ratios had fewer losses from sickness during labor-intensive agricultural seasons. Likewise, lower dependency ratios correlated significantly with fewer female sicknesses in the harvest season, demonstrating the seasonal labor-health contingency for households in Humla District (Table 7). However, even single-male households with higher dependency ratios were often forced to send males outside during strenuous agricultural seasons, and the strain on their labor resources resulted in poor health outcomes and, in turn, increased burdens on the household's ability to produce food (Table 8).

While better health outcomes were associated with larger and better quality fields overall, women's labor was disadvantaged by large and dispersed lands (58). GIS calculations showed that members of households with larger landholdings had significantly longer distances to travel to fields. Larger landholdings meant more female sicknesses in the nonharvest seasons and fewer in the harvest season, suggesting that demands associated with intense agricultural seasons in the Himalayas forced women to work even while they were sick (Table 9).

Figure 7. Male health was less affected by socioeconomic status than female health. 
Table 7. Pearson Correlations Between Household Composition and Sickness

\begin{tabular}{clcc}
\hline & & & Female \\
& & Sickness & Sickness \\
\hline Male- & Pearson correlation & $-0.326^{* *}$ & $-0.294^{*}$ \\
female & Sig. (two-tailed) & 0.005 & 0.012 \\
ratio & $n$ & 72 & 72 \\
Worker- & Pearson correlation & -0.111 & $-0.259^{*}$ \\
dependent & Sig. (two-tailed) & 0.362 & 0.032 \\
ratio & $n$ & 70 & 69 \\
\hline
\end{tabular}

*Significant at $p<0.05$. **Significant at $p<0.01$.

Enhanced by the information GIS reveals about workloads and health across space, these results suggest that outside earned income, more central to Uttargaon livelihoods, operated differently than other indicators of socioeconomic status in health outcomes and decisions. Higher income correlated with the use of cost-intensive first treatments (Table 10), meaning Humli villagers with more cash resources were able to pursue more treatment options than the villagers who had less cash on hand. However, the relationship between labor, topography, food production resources, and health in agriculturally based societies is complex. ArcGIS analysis showed that, in Humla, more fields means more travel to dispersed parcels. People who traveled farther to their fields tended to wait longer before attempting a first treatment of sickness (Table 11). Seasonal agricultural concerns were often prioritized above health treatment, especially among those households that depended more on agriculture for their livelihoods. Indeed, Humlis who prioritized nutrition and food (preventative health seeking via agricultural work) fared better than their neighbors who prioritized treatment. GIS imagery makes explicit Humlis' health-seeking rationale: topographical and resource variations were associated with different choices about treatment and demonstrate the difficulty of health access in the district.

\section{Social Resources and Health Seeking}

The importance of other human beings in both health-seeking and health outcomes, beyond the individuals experiencing the sickness episode and beyond the marital union, is a central theme revealed by the Humla health landscape. We have discussed the ways in which (a) healthcare development has been geared toward the individual and how some Humlis are taking advantage of this bias in service delivery while others are not and (b) how other members of the household may directly influence the health-seeking process. We continue and extend this conversation by exploring relationships between health, social resources, and geographical landscape within and beyond the household. GIS and microanalysis reveal the unexpected relationships involved in healthcare development in this and other developing regions.

Surprisingly, within the household, as we saw above, more people did not necessarily lead to a more active health-seeking regime. More people in the household was associated with less intensive first treatments and more intensive second treatments, the same pattern identified for the risk-averse Paschimgaon villagers (above). This finding highlights the ways in which healthcare and economic pursuits are brought into competition in agrarian livelihoods, especially in regions where scarce resources demand a strict and highly coordinated subsistence schedule (49). However, households with higher worker-to-dependent ratios tended to have lower levels of (mainly female) sickness during strenuous agricultural periods, again highlighting the importance of household composition in determining both health-seeking and health outcomes.

External to the household, nonkin political connections with people in the district capital correlated with more, and more intensive, third treatments for both villages in the study site, suggesting that households were drawing on social resources when sicknesses were particularly persistent or other resources had run out. The kin network maps in ArcGIS (Fig. 4) reveal the ways in which this plays out in Uttargaon's favor. Ethnographic evidence suggests that influential people at the district level helped out family and friends from the villages by providing loans to cover the cost of treatment, room and board for the duration of extravillage treatment, and/or facilitation of the health-seeking process at the district hospital using political muscle. In Nepal, informal

Table 8. Pearson Correlations Between Labor and Sickness

\begin{tabular}{llcc}
\hline & $\begin{array}{c}\text { Days Off } \\
\text { Work } \\
\text { due to } \\
\text { Sickness }\end{array}$ & $\begin{array}{c}\text { Days Off } \\
\text { Female } \\
\text { Work due to } \\
\text { Sickness }\end{array}$ \\
\hline Workers & Pearson correlation & $0.290^{*}$ & $0.263^{*}$ \\
outside the & Sig. (two-tailed) & 0.017 & 0.032 \\
village & $n$ & 67 & 67 \\
\hline
\end{tabular}

*Significant at $p<0.05$. * Significant at $p<0.01$. 
Table 9. Pearson Correlations Between Field Size and the Effects of Sickness on Female Labor

\begin{tabular}{llcc}
\hline & & $\begin{array}{c}\text { Female Work Days Lost to } \\
\text { Sickness-Harvest }\end{array}$ & $\begin{array}{c}\text { Female Work Days Lost to } \\
\text { Sickness-Early Summer }\end{array}$ \\
\hline Field size measured in labor days & Pearson correlation & $-0.286^{*}$ & $0.232^{*}$ \\
& Sig. (two-tailed) & 0.016 & 0.019 \\
& $n$ & 70 & 101 \\
\hline
\end{tabular}

*Significant at $p<0.05$. **Significant at $p<0.01$.

channels like these, connecting village Nepalis to more powerful patrons, traditionally defined the few pathways of power available to rural people (8). Likewise, higher numbers of neighboring kin were significantly associated with shorter wait periods before the first treatment, simultaneous use of several health treatments, and use of more than one treatment method for a given sickness. These results confirm ethnographic evidence that neighboring kin were an important resource in the health-seeking process. Kin were called upon to help sick people reach their treatment destinations; to provide money, food, or childcare so a parent could take a sick child to the hospital; or to provide labor if sickness befell during critical agricultural periods.

\section{CONCLUSIONS}

Although in many ways unique, the landscape of health and health seeking in Humla District as revealed by GIS analysis embodies and amplifies the complex nature of health service delivery in the developing world. Problems with healthcare development are clearly not the result of stupidity or malice on the part of villagers or development organizations, but of the unintended consequences of culture clashes within scarce environments. The findings presented above point to specific issues in health service delivery that are ripe for improvement in remote regions, and the ways in which GIS can improve our understandings of healthcare access in the developing world.
Health programs implemented by the NGOs in Humla District tended to conform to preexisting hierarchies of social status. The treatment system in Humla demands quantities of both time and cash, so those who were already more inclined to accept development workers, programs, and ideologies were also most able, economically, to reap its benefits. The true inequality exacerbated by the healthcare system in Humla, then, had to do with the status of having bikas (development) and knowing how to mobilize social resources to benefit from it. Ironically, this development savvy did not lead to better health status. In a reversal, the use of biomedical medicines and treatments conferred status on the users despite worse health outcomes in the short term. Comparisons between more developed and less developed villages using GIS revealed the landscape's effects on differences in diet, kin networks, and labor that led to such unexpected reversals in health seeking and health vulnerability.

We suggest this trend is part of a more general health-seeking transition brought about by rapid development in regions characterized by scarcity and remoteness. In its first stage, health seeking is locally available and low cost but there is still high mortality. In the interim stage, biomedical health services become available, but they are distant and costly, and only those who are heavily involved in the cash economy can take advantage of them. In this transition, though, the services themselves are unreliable and the costs of earning an income exact a great toll on user groups, and morbidity actually trends upward.

Table 10. Spearman's Rho Correlations Associating Income and Treatment Decisions

\begin{tabular}{llccc}
\hline & & $\begin{array}{c}\text { Cash Earned } \\
\text { During } \\
\text { Previous Year }\end{array}$ & $\begin{array}{c}\text { Equivalent of } \\
\text { Previous Year's } \\
\text { In-Kind Income }\end{array}$ & $\begin{array}{c}\text { Equivalent of } \\
\text { Total Income } \\
2009-2010\end{array}$ \\
\hline Cost-intensiveness of 1st method of & Correlation coefficient & $0.255^{*}$ & $0.286^{* *}$ & $0.233^{*}$ \\
treatment & Sig. (two-tailed) & 0.019 & 0.008 & 0.032 \\
& $n$ & 84 & 84 & 85 \\
\hline
\end{tabular}

*Significant at $p<0.05$. **Significant at $p<0.01$. 
Table 11. Pearson Correlations Between "Wait Times" Prior to Treatment and Distance to Fields

\begin{tabular}{llcc}
\hline & & $\begin{array}{c}\text { Average Distance } \\
\text { to Fields }\end{array}$ & $\begin{array}{c}\text { Average Distance } \\
\text { to Best Quality Fields }\end{array}$ \\
\hline $\begin{array}{l}\text { Period of time before first } \\
\text { treatment (days) }\end{array}$ & Pearson correlation & $0.397 * *$ & $0.502^{* *}$ \\
& Sig. (two-tailed) & 0.004 & 0.001 \\
& $n$ & 50 & 38 \\
\hline
\end{tabular}

**Significant at $p<0.01$.

Also, large families are essential to accomplishing household goals during this health-seeking transition, because economic opportunities and newly available health services are still so far away and highly volatile, demanding that households cast a wide net in the search for both cash and health services. They are willing to do so out of as much an imaginary development reality as an actual one (21). Presumably, in a third stage, improvements in the healthcare infrastructure, locally available education, and quality of services would combine with a more integrated cash economy, and health outcomes would improve at least for those who could afford the cost of services. This stage still does not privilege equitable healthcare access for all (45), and it hinges on the success of other forms of neoliberal development, such as the wholesale integration of the cash economy and the success of local business endeavors, by no means a foregone conclusion in places like Humla, nor an unmitigated good.
GIS analysis of the variation among villages and individuals in a single community also points to ways in which proponents of development can improve upon the success of their programs in order to build a more accessible healthcare landscape in Humla District and beyond. In 2009 and 2010 research, we observed the extent of successful adoption of NGOimplemented latrines that did appear to be negatively related to the prevalence of GI sickness in the fieldsite (Fig. 8). This, combined with high rates of gastrointestinal sickness in the fieldsite, indicates that development organizations have a potential role to play in healthcare improvements, if carried out wisely.

However, the vulnerabilities accompanying a health-seeking transition in remote regions of rapid development, demonstrated in this analysis, highlight particular policy areas requiring attention. A neoliberal focus on curative medicine obscures the key roles nutrition and social supports play in preventing sickness. These areas of sickness prevention need to

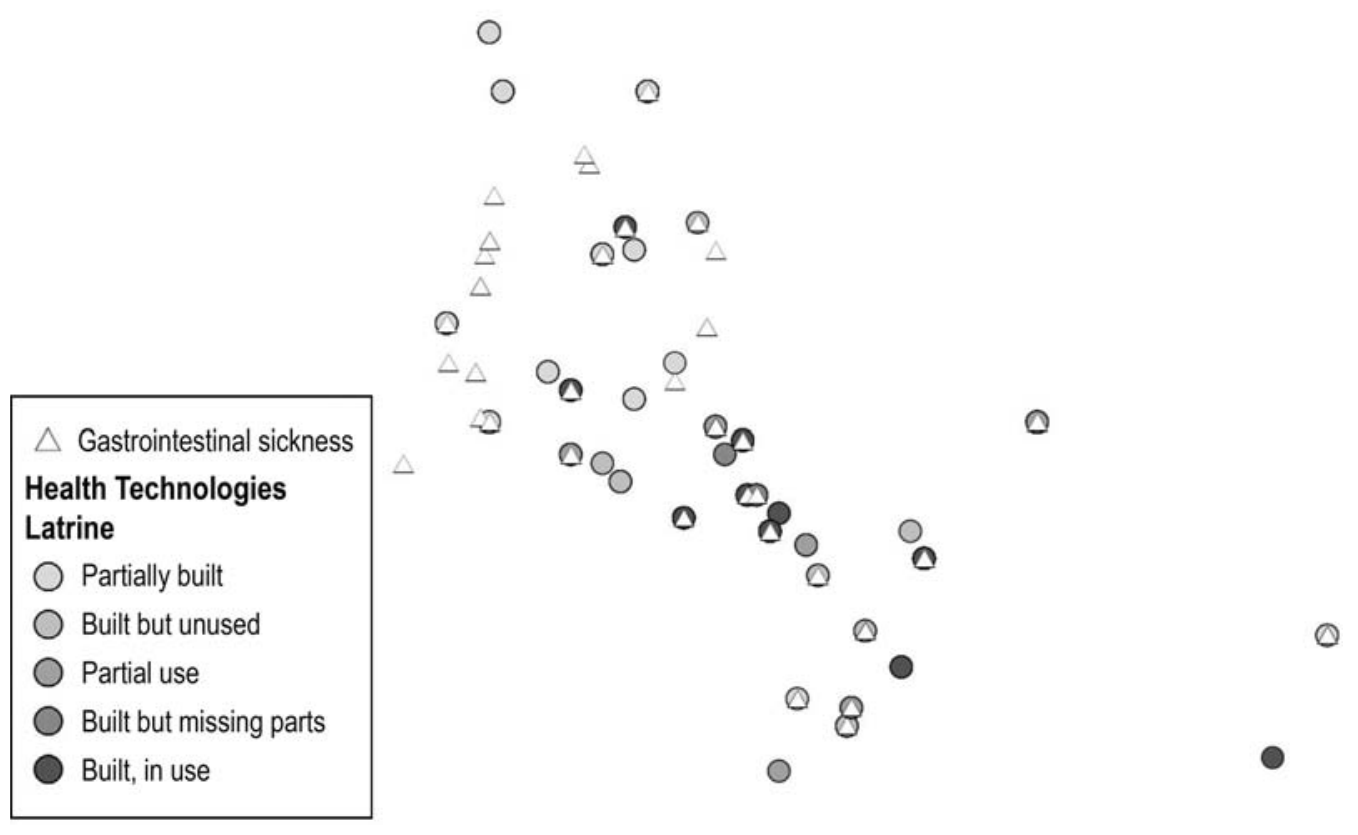

Figure 8. Gastrointestinal sickness clustered in wards lacking functional toileting systems. 
be incorporated in healthcare and other development programs to accommodate the transition to a cash economy. Next, while health infrastructure projects struggle to keep apace of the "global imaginary" (21) sought by local people, mobile health services that incorporate pluralistic health beliefs would go a long way to making health services more accessible. The range of differences between the two villages of the field site further demonstrates two other problems confronting healthcare development: first, the tendency of development projects to increase inequalities even in relatively homogeneous populations; and second, the range of vulnerabilities accompanying even micro-climatological differences, especially in mountainous environments. A one-size-fits-all approach to healthcare development will exacerbate inequalities and deepen vulnerabilities specific to varied ecopolitical contexts.

GIS research can illuminate the pathways to successful healthcare development by connecting social network information to the landscape properties that facilitate or form barriers to human health. Those who have studied the diffusion of innovations in South Asia note the continued importance of geography and information sources to adoption of new innovations $(3,9,10,19,39,42)$. Geography, especially in conflict settings, may impact access to innovations physically and socially through people's relationships and experiences (17). Therefore, decisions to participate in conflicts and engage with development are parts of broader social patterns, embedded in remote landscape features, and influenced in multiple ways by the geographic and social characteristics of networks in which people are immersed. Identifying those features that affect development success is key to the design of health development programs and one forte of GIS analysis.

ACKNOWLEDGMENTS: Support for this research was provided by the National Science Foundation, the ISIS Foundation, and the Bertha Morton Foundation. Matthew Nordhagen's help with ArcGIS was invaluable. Foremost, thanks are due to the people of Humla District and Nepal who welcomed us and made this research possible. The authors declare no conflicts of interest.

\section{REFERENCES}

1. Agarwal, B. Social security and the family: Coping with seasonality and calamity in rural India. J. Peasant Stud. 17(3):341-412; 1990.
2. ArcGIS Resource Center. XY to line (data management). Retrieved November 2012, from http://help.arcgis.com/en/ arcgisdesktop/10.0/help/index.html\#//0017000000tv 000000

3. Bajaj, S. S.; Nayak, H. S. Impact of information sources on the adoption of high yielding paddy variety. Adibasi 24(1/2):S45-48; 1984.

4. Barrett, R.; Kuzawa, C. W.; McDade, T.; Armelagos, G. J. Emerging and reemerging infectious diseases: The third epidemiologic transition. Annu. Rev. Anthropol. 27:247-271; 1998.

5. Bell, C. A. The people of Tibet. Oxford, UK: Clarendon Press; 1928.

6. Berreman, G. D. Hindus of the Himalayas: Ethnography and change. Oxford: Oxford University Press; 1963.

7. Bishop, B. C. Karnali under stress: Livelihood strategies and seasonal rhythms in a changing Nepal Himalaya. Chicago: University of Chicago; 1990.

8. Bista, D. B. Fatalism and development: Nepal's struggle for modernization. Kathmandu: Tribhuvan University; 1991.

9. Boulay, M.; Storey, J. D.; Sood, S. Indirect exposure to a family planning mass media campaign in Nepal. J. Health Commun. 7(5):379-399; 2002.

10. Brown, S. Spatial analysis of socioeconomic issues: Gender and GIS. Mt. Res. Dev. 23(4):338-344; 2003.

11. Carter, M. R. Environment, technology, and social articulation of risk in West African agriculture. Econ. Dev. Cult. Change 45(3):557-590; 1997.

12. Citrin, D. M. The anatomy of ephemeral health care: "Health camps" and short-term medical voluntourism in remote Nepal. SINHAS 15(1):27-72; 2010.

13. Collier, S. The spatial forms and social norms of 'actually existing neoliberalism': Toward a substantive analytics. International Affairs Working Paper. New York, NY: New School University; 2005.

14. Department for International Development. Sustainable livelihood guidance sheets. London: Department for International Development; 2000.

15. Ellison, J. Governmentality and the family: Neoliberal choices and emergent kin relations in Southern Ethiopia. Am. Anthropol. 111(1):81-92; 2009.

16. Ensminger, M. E.; Fothergill, K. E. A decade of measuring SES: What it tells us and where to go from here. In: Bornstein, M. H.; Bradley, R. H., eds. Socioeconomic status, parenting, and child development. Mahwah: Lawrence Erlbaum Associates; 2003:13-28.

17. Fisher, E.; Holland, J. D. Social development as knowledge building: Research as a sphere of policy influence. J. Int. Dev. 15:911-924; 2003.

18. Fisher, J. F. Trans-Himalayan traders: Economy, society and culture in Northwestern Nepal. Delhi: Motilal Banarsidass; 1987.

19. Fissel, A.; McKay, K. H. Action! Why people engaged in the fight against HIV/AID should take note of traditional healer organizations in Uganda. Prac. Anthropol. 28(4): 22-25; 2006.

20. Fricke, T. Introduction: Human ecology in the Himalaya. Hum. Ecol. 17(2):131-145; 1989. 
21. Friedman, J. Globalization and the making of a global imaginary. In: Stald, G.; Tufte, T., eds. Global encounters: Media and cultural transformation. Luton: University of Luton Press; 2001:13-31.

22. Good, B. J. The heart of what's the matter: The semantics of illness in Iran. Cult. Med. Psychiatry 1:25-58; 1977.

23. Henrich, J.; McElreath, R. Are peasants risk-averse decision makers? Curr. Anthropol. 43(1):172-181; 2002.

24. Heyman, J. M. The anthropology of power-wielding bureaucracies. Hum. Organ. 63(4):487-500; 2004.

25. Hoy, P. Players and issues in international aid. West Hartford, CT: Kumarian Press, Inc.; 1998:1-150.

26. Hunter, W. W. Statistical account of the Khasi and Jaintia Hills. London: Trubner \& Co. 1897:203-255.

27. Hutchinson, S. The cattle of money and the cattle of girls among the Nuer, 1930-83. In: Grinker, R. R.; Steiner, C. B., eds. Perspectives on Africa: A reader on culture, history, and representation; Oxford: Blackwell; 1997:190-209.

28. Jamison, D. T.; Breman, J. G.; Mesham, A. R.; Alleyne, G.; Claeson, M.; Evans, D. B.; Jha, P.; Mills, A.; Musgrove, P. Disease control priorities in developing countries, second edition. Washington, DC: The World Bank; 2006:1-34.

29. Jerstad, L. G. Mani-Rimdu: Sherpa dance drama. Seattle, WA: University of Washington Press; 1969:24-25.

30. Justice, J. Policies, plans, and people: Culture and health development in Nepal. Berkeley, CA: University of California Press; 1986.

31. Justice, J. Neglect of cultural knowledge in health planning: Nepal's assistant nurse-midwife program. In: Hahn, R. A., ed. Anthropology in public health: Bridging differences in culture and society. Oxford: Oxford University Press, Inc.; 1999:327-344.

32. Kedia, S. Changing food production strategies among Garhwali settlers in the Himalayas. Ecol. Food Nutr. 43: 421-442; 2004.

33. Leatherman, T. L. A biocultural perspective on health and household economy in Southern Peru. Med. Anthropol. Q. 10(4):476-495; 1996.

34. Leslie, C. Medical pluralism in world perspective. Soc. Sci. Med. 14B:191-195; 1980.

35. Levine, N. E. The dynamics of polyandry: Kinship, domesticity and population on the Tibetan border. Chicago, IL: University of Chicago Press; 1988.

36. McCormack, A. P. Khasis. New Haven, CT: Human Relations Area Files; 1964:111-112.

37. McElroy, A. health ecology in Nunavut: Inuit elders' concepts of nutrition, health, and political change. In: Guest, G., ed. Globalization, health, and the environment. Lanham: Alta Mira Press. 2005:107-131.

38. McKay, K. H. Challenges to health care access in Maoist Nepal. Himalayan XXIII(2):43-46; 2003.

39. Mull, D. Anthropological perspectives on childhood pneumonia in Pakistan. In: Hahn, R. A., ed. Anthropology in public health: Bridging differences in culture and society. New York: Oxford University Press; 1999:84-114.

40. Nakane, C. Garo and Khasi: A comparative study in matrilineal systems. Paris, France: Mouton; 1967:22.
41. Netting, R. M. Smallholders, householders: Farm families and the ecology of intensive, sustainable agriculture. Stanford, CA: Stanford University Press; 1993.

42. Nichter, M.; Nichter, M. Modern methods of fertility regulation: When and for whom are they appropriate? In: Nichter, M; Nichter, M., eds. Anthropology and international health: Asian case studies. Tucson, AZ: Gordon and Breach Publishers; 1996:71-108.

43. Nichter, M. Global health: Why cultural perceptions, social representations, and biopolitics matter. Tucson, AZ: University of Arizona Press; 2008:133-152.

44. Oakes, J. M.; Rossi, P. H. The measurement of SES in health research: Current practice and steps toward a new approach. Soc. Sci. Med. 56:769-784; 2003.

45. Odaga, J. From Alma Ata to millennium development goals: To what extent has equity been achieved? Health Policy Dev. 2(1):1-16; 2004.

46. Omran, A. R. The epidemiologic transition: A theory of the epidemiology of population change. Milbank Q. 49(4):509537; 1971.

47. Orlove, B. S.; Guillet, D. W. Theoretical and methodological considerations on the study of mountain peoples: Reflections on the idea of subsistence type and the role of history in human ecology. Mt. Res. Dev. 5(1):3-18; 1985.

48. Panter-Brick, C. Motherhood and subsistence work: The Tamang of rural Nepal. Hum. Ecol. 17(2):205-228; 1989.

49. Panter-Brick, C. Seasonal organization of work patterns. In: Ulijaszeck, S. J.; Strickland, S. S., eds. Seasonality and human ecology. Cambridge: Cambridge University Press; 1993:220-234.

50. Pickering, A.; McKay, K. H. Old and new barriers to family planning in Humla, Nepal: How the urban/rural divide has widened. CTNS 34(1):229-245; 2007.

51. Pigg, S. L. Inventing social categories through place: Social representations and development. Comp. Stud. Soc. Hist. 34(3):491-513; 1992.

52. Reich, M. R. Reshaping the state from above, from within, from below: Implications for public health. Soc. Sci. Med. 54:1669-1675; 2002.

53. Scott, J. C. The moral economy of the peasant. New Haven, CT: Yale University Press; 1976.

54. Scott, J. C. The art of not being governed: An anarchist history of upland Southeast Asia. Hartford, CT: Yale University Press; 2009.

55. Singer, M.; Clair, S. Syndemics and public health: Reconceptualizing disease in biosocial context. Med. Anthropol. Q. 17(4):423-441; 2003.

56. Stash, S. Explanations of unmet need for contraception in Chitwan, Nepal. Stud. Fam. Plann. 30(4):267-287; 1999.

57. Uchino, B. N.; Cacioppo, J. T.; Kiecolt-Glaser, J. K. The relationship between social support and physiological processes: A review with emphasis on underlying mechanisms and implications for health. Psychol. Bull. 119(3):488531; 1996.

58. Wiley, A. S. An ecology of high altitude infancy: A biocultural perspective. Cambridge, UK: Cambridge University Press; 2004. 